\title{
PENERAPAN ALGORITMA C4.5 UNTUK PENJURUSAN SISWA SEKOLAH MENENGAH ATAS
}

\author{
Rina Kurniasari ${ }^{1}$, Azizah Fatmawati ${ }^{2}$ \\ ${ }^{1,2}$ Program Studi Informatika, Fakultas Komunikasi dan Informatika, \\ Universitas Muhammadiyah Surakarta \\ Jl. Ahmad Yani, Pabelan, Kartasura, Surakarta 57102, Telp: +62(271)717417 \\ E-mail : rinakurnia768@gmail.com ${ }^{1}$, af157@ums.ac.id ${ }^{2}$
}

\begin{abstract}
ABSTRAK
Jurusan di Sekolah Menengah Atas (SMA) digunakan sebagai acuan untuk menyalurkan bakat dan kemampuan dari siswa. Penjurusan tersebut dilakukan ketika pendaftaran siswa baru, sebelum siswa tersebut diterima sebagai siswa kelas X. Banyaknya data siswa yang melakukan pendaftaran dan pelaksanaan penjurusan saat ini yang masih menggunakan sistem manual, mengakibatkan terjadinya kesalahan dan waktu pengolahan data yang cukup lama. Penelitian ini bertujuan mengembangkan sistem untuk mengklasifikasikan jurusan bagi siswa dengan tepat, efektif dan efisien. Metode penelitian yang digunakan dalam penelitian ini dengan menerapkan. Algoritma C4.5 untuk mengklasifikasikan siswa dalam menentukan jurusan. Algoritma C4.5 digunakan untuk mencari pola-pola aturan berdasarkan variabel pendukung berupa nilai rata-rata raport Sekolah Menengah Pertama (SMP), nilai tes akademik seperti nilai mata pelajaran Ilmu Pengetahuan Alam (IPA), nilai mata pelajaran Ilmu Pengetahuan Sosial (IPS), dan nilai Bahasa. Hasil dari penelitian ini sendiri berupa aplikasi data mining dengan Algoritma C4.5 untuk memprediksi penjurusan IPA, IPS, atau Bahasa. Tingkat akurasi yang didapatkan sebesar 97,42\%.
\end{abstract}

Kata kunci: Algoritma C4.5, Klasifikasi, Penjurusan

\section{PENDAHULUAN}

Kurikulum yang diterapkan di Sekolah Menengah Atas (SMA) saat ini menggunakan kurikulum 2013. Kurikulum 2013 membagi jurusan menjadi 3 yaitu IPA, IPS, dan Bahasa yang mana proses penjurusan tersebut dilakukan ketika pendaftaran siswa baru sebelum diterima sebagai siswa kelas $\mathrm{X}$. Proses penjurusan tersebut masih menggunakan sistem manual dengan tulis tangan di kertas padahal jumlah data siswa yang mendaftar cukup banyak dan menyebabkan terjadinya kesalahan dan memasukkan data dan waktu yang diperlukan cukup lama dalam mengolah data. Perlu adanya klasifikasi untuk permasalahan tersebut.
Cara untuk melakukan klasifikasi yaitu dengan teknik data mining menggunakan Algoritma C4.5.

Data mining adalah suatu algoritma di dalam menggali informasi berharga yang erpendam atau tersembunyi pada suatu koleksi data (database) yang sangat besar sehingga ditemukan suatu pola yang menarik yang sebelumnya tidak diketahui [1]. Algoritma C4.5 yaitu sebuah algoritma yang digunakan untuk membangun decision tree (pengambilan keputusan) [2]. Pohon keputusan sendiri merupakan metode klasifikasi dan prediksi yang sangat kuat dan terkenal dan metode pohon keputusan mengubah fakta yang sangat besar menjadi pohon keputusan yang merepresentasikan aturan [1]. Manfaat utama dari penggunaan pohon keputusan adalah kemampuannya untuk mem-break down proses pengambilan keputusan yang kompleks menjadi lebih simpel sehingga pengambil keputusan akan lebih menginterpretasikan solusi dari permasalahan [1]. Nugroho [3] dalam penelitiannya mengenai klasifikasi predikat kelulusan mahasiswa yang menggunakan Algoritma C4.5 menghasilkan akurasi sebesar $73.91 \%$. Swastina [4], dalam penelitian Algoritma Decision Tree C4.5 akurat diterapkan untuk penentuan kesesuaian jurusan mahasiswa dengan tingkat akurasi 93,31 \% dan akurasi rekomendasi jurusan sebesar 82,64\%. Maka dapat disimpulkan penggunaan Algoritma C4.5 dalam klasifikasi menghasilkan tingkat akurat yang cukup tinggi dan cocok untuk prediksi jurusan yang peneliti lakukan.

Bedasarkan latarbelakang yang dijelaskan di atas maka penelitian ini dilakukan untuk mengembangkan sistem dengan menerapkan data mining menggunakan Algoritma C4.5 guna memprediksi dan mengklasifikasi penentuan jurusan siswa SMA.

\section{ISI PENELITIAN}

\subsection{Tinjauan Pustaka \\ 2.1.1 Data Mining}

Data mining merupakan proses pencarian informasi dari sekumpulan data yang besar dan tidak diketahui sebelumnya. Adapun Karakteristik data mining sebagai berikut [5]: 
a. Data mining berhubungan dengan penemuan sesuatu yang tersembunyi dan pola data tertentu yang tidak diketahui sebelumnya.

b. Data mining biasa menggunakan data yang sangat besar. Biasanya data yang besar digunakan untuk membuat hasil lebih dipercaya.

c. Data mining berguna untuk membuat keputusan yang kritis, terutama dalam strategi

Dalam aplikasinya, data mining sebenarnya merupakan salah satu bagian proses Knowledge Discovery in Database (KDD) yang bertugas untuk mengekstrak pola atau model dari data dengan menggunakan suatu algoritma yang spesifik [6].

Adapun proses KDD sebagai berikut [7]:

1) Data Selection: pemilihan data dari sekumpulan data operasional perlu dilakukan sebelum tahap penggalian informasi dalam KDD dimulai.

2) Preprocessing: sebelum proses data mining dapat dilaksanakan, perlu dilakukan proses cleaning dengan tujuan untuk membuang duplikasi data, memeriksa data yang inkonsisten, dan memperbaiki kesalahan pada data, seperti kesalahan cetak (tipografi). Juga dilakukan proses enrichment, yaitu proses "memperkaya" data yang sudah ada dengan data atau informasi lain yang relevan dan diperlukan untuk KDD, seperti data atau informasi eksternal.

3) Transformation: yaitu proses coding pada data yang telah dipilih, sehingga data tersebut sesuai untuk proses data mining. Proses coding dalam KDD merupakan proses kreatif dan sangat tergantung pada jenis atau pola informasi yang akan dicari dalam database.

4) Data mining: proses mencari pola atau informasi menarik dalam data terpilih dengan menggunakan teknik atau metode tertentu.

5) Interpretation / Evaluation: pola informasi yang dihasilkan dari proses data mining perlu ditampilkan dalam bentuk yang mudah dimengerti oleh pihak yang berkepentingan. Tahap ini merupakan bagian dari proses KDD yang disebut dengan interpretation. Tahap ini mencakup pemeriksaan apakah pola atau informasi yang ditemukan bertentangan dengan fakta atau hipotesa yang ada sebelumnya atau tidak.

\subsubsection{Pohon Keputusan (Decision Tree)}

Pohon keputusan merupakan model prediksi menggunakan struktur pohon, selain karena pembangunannya relatif cepat, hasil dari model yang dibangun juga mudah untuk dipahami, sehingga Decision Tree ini merupakan metode klasifikasi yang paling popular digunakan [5]

\subsubsection{Algoritma C4.5}

Algoritma C4.5 merupakan algoritma yang membangun pohon keputusan dan membentuk model pengetahuan untuk mengklasifikasikan data dan Algoritma C4.5 memiliki performa tercepat dan memiliki akurasi yang paling tinggi [8].

\subsection{Metodologi}

Metode penelitian yang digunakan dalam penelitian ini yaitu Pengumpulan data, Preprocessing data, Model yang diusulkan, Implementasi sistem Pengujian model, Evaluasi dan dan validasi model.

\subsubsection{Pengumpulan Data}

Data yang digunakan dalam penelitian ini didapatkan dari data siswa kelas X SMA 6 Surakarta tahun ajaran 2017/2018. Selain itu ada data yang didapatkan berdasarkan literatur review jurnal, buku yang berhubungan dengan permasalahan yang diteliti.

\subsubsection{Preprocessing Data}

Preprocessing Data merupakan proses awal pengolahan data. Dalam data mining kualitas dari data yang akan digunakan perlu diperhatikan. Ada beberapa faktor preprocessing data yang mempengaruhi kualitas data, antara lain keakuratan, keutuhan, konsistensi, aktualitas, dan penafsiran [9] Data yang diperolah dari pihak SMA 6 Surakarta meliputi nama siswa, nisn, rata-rata nilai raport SMP, minat siswa, dan nilai tes akademik berupa nilai IPA, nilai IPS, dan nilai Bahasa. Kemudian jurusan yang akan dipilih ada 3 yaitu IPA, IPS, dan Bahasa.

\subsubsection{Model yang diusulkan}

Model yang diusulkan untuk menentukan jurusan siswa SMA yaitu menggunakan Algoritma C4.5. Secara umum Algoritma C4.5 akan membangun pohon keputusan.

Tahapan model Algoritma C4.5 sebagai berikut [4]:

1) Menyiapkan data training. Data training digunakan untuk membentuk model yang akan diterapkan pada data uji.

2) Menentukan akar dari pohon.

3) Menentukan nilai dari gain. Perhitungan gain dirumuskan pada persamaan berikut.

$$
\text { Gain }=\text { Entropy }\left(S_{i}\right)-\sum_{i=1}^{n} \frac{|S i|}{s} \approx \text { Entropy (Si) (1) }
$$

Keterangan:

$\mathrm{S}=$ Himpunan kasus

$\mathrm{A}=$ Fitur

$\mathrm{n}=$ jumlah partisi atribut $\mathrm{A}$

$|\mathrm{Si}|=$ proporsi Si terhadap $\mathrm{S}$

|S $\mid=$ jumlah kasus dalam $S$

Sebelum menentukan nilai gain terlebih dahulu menghitung nilai entropy. Perhitungan entropy adalah perhitungan untuk mencari nilai yang nantinya dapat dijadikan cabang dengan nilai 0 (nol) atau nilai yang terendag dari ssemua atribut [10].

Perhitungan entropy dirumuskan pada persamaan berikut.

$\operatorname{Entropy}(S)=\sum_{i=1}^{n}-p i \log _{2} p i$ 
Keterangan:

$\mathrm{S}=$ Himpunan kasus

$\mathrm{n}=$ Jumlah partisi $\mathrm{S}$

$\mathrm{P}_{\mathrm{i}}=$ proporsi $\mathrm{S}_{\mathrm{i}}$ terhadap $\mathrm{S}$

4) Mengulangi langkah 2 hingga semua tupel terpartisi.

5) Proses partisi pohon keputusan akan berhenti saat semua tupel dalam node $\mathrm{N}$ mendapat kelas yang sama atau tidak ada atribut di dalam tupel yang dipartisi lagi dan atau tidak ada tupel di dalam cabang yang kosong.

\subsubsection{Implementasi Sistem}

Pada tahap implementasi sistem dibangun sistem menggunakan bahasa pemrograman PHP (Hypertext Prepocessor), menggunakan tools xampp, notepad++ sebagai text editor dan menyimpan database dalam MySql. Pada implementasi sistem diterapkan Algoritma C4.5 berdasarkan rumus yang telah dijelaskan di metode model yang diusulkan. Selain menggunakan sistem, penerapan Algoritma C4.5 dilakukan dengan perhitungan melalui Microsoft Excel. Kemudian dibandingkan hasil perhitungan excel dan sistem sesuai atau tidak.

\subsubsection{Pengujian}

Pada tahap pengujian melakukan proses pengukuran data seperti mengukur recall, precision, dan accuracy. Pengujian dalam penelitian menggunakan software pendukung yaitu Rapid Miner 7.6. Perhitungan accuracy, recall dan precission dapat dirumuskan pada persmaan berikut [11].

Precision adalah perhitungan terhadap perkiraan proporsi kasus yang benar dan dirumuskan pada Persamaan 3.

$$
\text { Precission }=\frac{\mathrm{TP}}{\mathrm{TP}+\mathrm{FP}}
$$

Recall adalah perhitungan terhadap perkiraan proporsi kasus positif yang diidentifikasikan benar dan dirumuskan pada Persamaan 4.

$$
\text { Recall }=\frac{\mathrm{TP}}{\mathrm{TP}+\mathrm{TN}}
$$

Accuracy adalah perhitungan terhadap proporsi dari jumlah total prediksi yang benar dan dirumuskan dalam Persamaan 5.

$$
\text { Accuracy }=\frac{\mathrm{TP}+\mathrm{TN}}{\mathrm{TP}+\mathrm{FN}+\mathrm{FP}+\mathrm{TN}}
$$

Keterangan:

$\mathrm{TP}($ True Positives $)=$ Jumlah objek positif yang benar diklasifikasikan

$\mathrm{TN}($ True Negatives $) \quad=$ Jumlah objek negatif yang salah diklasifikasikan
FP (False Positives) = Jumlah objek negatif yang benar diklasifikasikan

FN (False Negatives) = Jumlah objek positif yang salah diklasifikasikan

\subsection{Hasil Dan Pembahasan}

2.3.1 Perhitungan Manual Algoritma C4.5.

Perhitungan manual dilakukan menggunakan aplikasi Microsoft excel. Perhitungan ini dilakukan untuk menghitung nilai gain dan entropy dari tiap atribut. Kemudian dari perhitungan tersebut akan didapatkan pohon keputusan sebagai aturan guna membantu penentuan jurusan bagi siswa. Adapun atribut yang digunakan dalam penentuan jurusan yaitu:

1. Nilai Rata-rata Raport SMP, dikelompokkan dengan variabel Rendah (0-50), Sedang (51-75), Tinggi (76-100).

2. Minat siswa dengan variable IPA, IPS, dan Bahasa.

3. Nilai tes akademik IPS, dikelompokkan dengan variable Rendah (0-50), Sedang (51-75), Tinggi (76-100).

4. Nilai tes akademik IPS, dikelompokkan dengan variable Rendah (0-50), Sedang (51-75), Tinggi (76-100).

5. Nilai tes akademik Bahasa, dikelompokkan dengan variable Rendah (0-50), Sedang (51-75), Tinggi (76-100).

Adapun contoh 10 data training dalam sistem yang

\begin{tabular}{|c|c|c|c|c|c|c|c|c|}
\hline No & Nisn & Nama & $\begin{array}{c}\text { Rata-rate } \\
\text { Raport }\end{array}$ & Minat & $\begin{array}{c}\text { Nilai } \\
\text { IPA }\end{array}$ & $\begin{array}{c}\text { Nilai } \\
\text { IPS }\end{array}$ & $\begin{array}{c}\text { Vilai } \\
\text { Rahasa }\end{array}$ & Jurusan \\
\hline 1. & 111 & Siswa 1 & 83.34 & $P A$ & 76 & 67 & 89 & $\mathrm{TPA}$ \\
\hline 2. & 112 & Siswa 2 & 83.57 & $\mathbb{P A}$ & 80 & 49 & 67 & IPA \\
\hline 3. & 113 & Siswa 3 & 84.76 & PS & 76 & 57 & 86 & IPA \\
\hline 4. & 114 & Siswd 4 & 85.12 & LPS & 56 & 87 & 76 & IPS \\
\hline 5. & 115 & Siswa 5 & 86.98 & IPS & 47 & 89 & 88 & Rahasa \\
\hline 6. & 116 & Siswa 6 & 86 & $\mathrm{IAA}$ & 87 & 54 & 45 & IPA \\
\hline 7. & 117 & Siswa ? & 80 & $P A$ & 52 & 83 & 79 & IPS \\
\hline 8. & 118 & Siswa 8 & 79.33 & Bahlas:a & 56 & 93 & 95 & Buhlasta \\
\hline 9. & 119 & Siswa 9 & 80.76 & Rahasa & 67 & 67 & 94 & Bahasa \\
\hline 10. & 120 & Siswa 10 & 78.56 & Bahasa & 56 & 87 & 91 & IPS \\
\hline
\end{tabular}
dikembangkan ditunjukkan pada Tabel 1.

Tabel 1. Contoh Data Training

Selanjutnya data training yang masih memiliki nilai numeric diubah menjadi variabel rendah, sedang atau tinggi seperti yang ditunjukkan pada Tabel 2 . 
Vol. 8, No. 1, Maret 2019, ISSN : 2089-9033, eISSN : 2715-7849

Tabel 2. Konversi Data Training

\begin{tabular}{|c|c|c|c|c|c|c|c|c|}
\hline No & 111 & Siswa 1 & $\begin{array}{l}\text { Rata-rata } \\
\text { Raport } \\
\text { Tingsi }\end{array}$ & Minat & $\begin{array}{c}\text {.ïlai } \\
\text { IPA } \\
\text { Tingyi } \\
\end{array}$ & $\begin{array}{c}\text { Nilai } \\
\text { IPS } \\
\text { Sedany }\end{array}$ & $\begin{array}{c}\text { Nilai } \\
\text { Bahasa } \\
\text { Tingui }\end{array}$ & Jurusan. \\
\hline 2. & 112 & Siswa 2 & Tinggi & IPA & Tingei & Rendat. & Sedang & IPA \\
\hline 3. & 113 & Siswa 3 & Tinggi & IPS & Tinggi & Sedang & Tinggi & IPA \\
\hline 4. & 114 & Siswa 4 & Tinggi & IPS & Sedang & Tinggi & Tinggi & IPS \\
\hline 5. & 115 & Siswa 5 & Tinggi & IPS & Rendah & Tinggi & Tinggi & Bahasa \\
\hline 6. & 116 & Siswa 6 & linggi & IPA & Tinggi & Sierlang & Rendah & IPA \\
\hline 7 & $11 ?$ & Siswa 7 & Tinggi & $\mathrm{IPA}$ & Sedang & Tinggi & Tinggi & IPS \\
\hline 8. & 118 & Siswa 8 & Tinggi & Bahasa & Sedang & Tinggi & Tinggi & Bahasa \\
\hline 9. & 119 & Siswa 9 & Tingsi & Bahrasa & Setdany & Sedally & Tingui & Bahasa \\
\hline 10. & 120 & Siswa 10 & Tinggi & Bahasa & Sedang & Tinggi & Tinggi & IPS \\
\hline
\end{tabular}

Selanjutnya melalukan perhitungan entropy dan gain masing masing atribut. Dari hasil perhitungan node 1 pada Tabel 3 didapatkan nilai gain tertinggi tertinggi 0, 920081259 pada Nilai IPA. Nilai IPA dijadikan sebagai akar atau node dari pohon keputusan. Nilai IPA memiliki tiga atribut yaitu rendah, sedang, dan tinggi. Ketiga atribut tersebut belum mempunyai keputusan, maka selanjutnya dilakukan perhitungan entropy dan gain untuk masing-masing atribut sampai menghasilkan keputusan. Perhitungan node 1 ditunjukkan pada Tabel 3.

Tabel 3. Perhitungan node 1

\begin{tabular}{|c|c|c|c|c|c|c|c|}
\hline ATRAEU & WRLE & $\begin{array}{l}\text { IUMLAH } \\
\text { KAS_S }\end{array}$ & IFA & PS & 3anasa & ENTFOPY & $\begin{array}{l}\text { INFC RMATIONN } \\
\text { GMIN }\end{array}$ \\
\hline TOTAL & & 196 & 80 & so & 26 & $-1-2985235$ & \\
\hline \multirow{4}{*}{ MINAT } & IPA & 71 & 35 & 12 & 4 & $0,952643 \times 2$ & \\
\hline & IPS & $n$ & 14 & 65 & 3 & 0,857151.5 & \\
\hline & Be ledse & 42 & 11 & 12 & 19 & $1,5 \angle 0319314$ & \\
\hline & & & & & & & 0,386628284 \\
\hline \multirow{4}{*}{$\begin{array}{l}\text { RATA-RATA } \\
\text { N\|A }\end{array}$} & RENUAA- & $\mathrm{s}$ & $\mathrm{c}$ & 9 & 0 & 0 & \\
\hline & SFDANG & 39 & 30 & 45 & 7 & , 3n 344344 & \\
\hline & TINGG & 104 & 50 & 35 & 19 & 1,484782524 & \\
\hline & & & & & & & 0,090036005 \\
\hline \multirow{4}{*}{$N \| \Delta \mid \mathbb{P} A$} & RENUA- & $2 b$ & 0 & 10 & 16 & u,sioysubsi & \\
\hline & SLDANG & 36 & c & 75 & 10 & 0,518569732 & \\
\hline & TINGG & 35 & 80 & 4 & 1 & 0,305223317 & \\
\hline & & & & & & & 0,920081259 \\
\hline \multirow{4}{*}{ NI LA IFS } & RENDA- & 14 & 13 & 0 & 1 & 0,371232327 & \\
\hline & STDANG & s? & का & 4 & 25 & 1, (202\%า & \\
\hline & TNGG & 93 & 7 & 85 & 0 & 0,385285119 & \\
\hline & & & & & & & C, 721385036 \\
\hline \multirow{4}{*}{ N/ I A Rahs: :A } & RENUA- & 2 & 3 & $1 i$ & 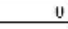 & $0, / / 3226 \mathrm{~b} / 420,63$ & \\
\hline & SEUANG & 141 & is & to & 0 & u,5y/ubeis; & \\
\hline & TINGGE & 39 & a & 7 & $2 \pi$ & 0,745517343 & \\
\hline & & & & & & & 0,50025657 \\
\hline
\end{tabular}

Dari hasil perhitungan node 1.1 untuk kondisi Nilai IPA rendah pada Gambar 5 didapatkan nilai gain tertinggi tertinggi 0, 970950594 pada Nilai IPS. Ada tiga nilai atribut nilai IPS yaitu rendah, sedang dan tinggi. Nilai atribut rendah tidak dapat mengklasifikasikan karena semua atribut bernilai 0 . Nilai atribut sedang mengklasifikasikan kasus data dan menghasilkan keputusan Bahasa. Nilai atribut tinggi mengklasifikasikan kasus data dan menghasilkan keputusan IPS. Perhitungan node 1.1 ditunjukkan pada Tabel 4.
Tabel 4. Perhitungan node 1.1

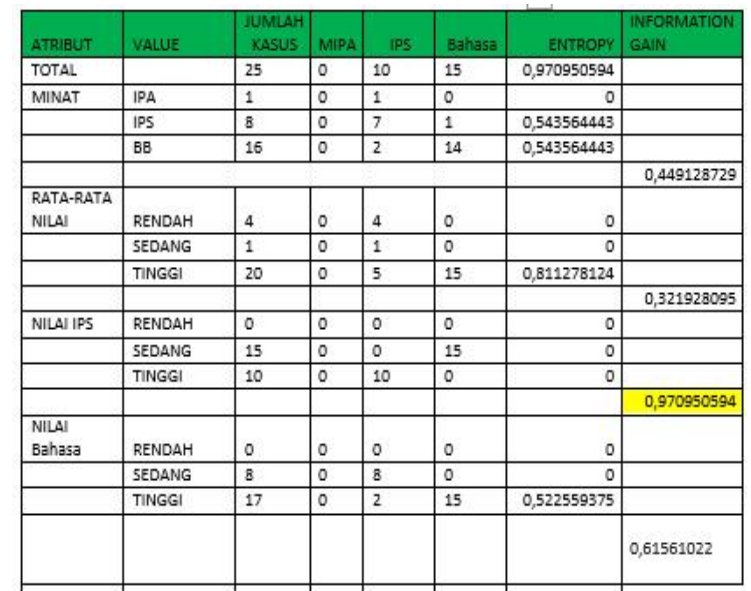

Dari hasil perhitungan node 1.2 untuk kondisi Nilai IPA sedang pada Tabel 5 didapatkan nilai gain tertinggi 0,3896053 pada Nilai IPS. Nilai IPS mempunyai atribut rendah, sedang, dan tinggi. Atribut rendah mengklasifikasikan kasus data dan menghasilkan keputusan Bahasa. Atribut tinggi mengklasifikasikan kasus data dan menghasilkan keputusan IPS. Sedangkan atribut sedang belum menghasilkan keputusan sehingga perlu dilakukan perhitungan entropy dan gain pada kondisi Nilai IPA sedang dan nilai IPS sedang. Perhitungan node 1.2 ditunjukkan Pada Tabel 5.

Tabel 5. Perhitungan node 1.2

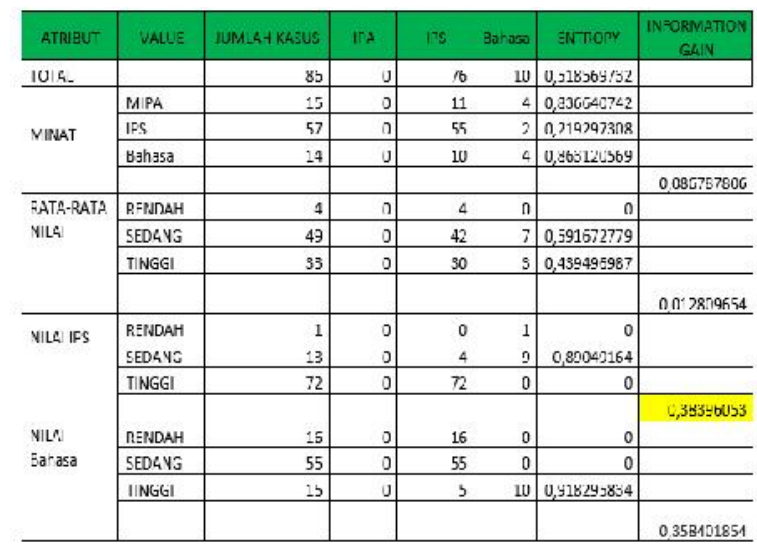

Dari hasil perhitungan node 1.2.1 untuk kondisi Nilai IPA sedang dan Nilai IPS sedang pada Gambar 7 didapatkan nilai gain tertinggi 0,890491640 pada Nilai Bahasa. Ada tiga nilai atribut nilai Bahasa yaitu rendah, sedang dan tinggi. Nilai atribut rendah tidak dapat mengklasifikasikan karena semua atribut bernilai 0 . Nilai atribut sedang mengklasifikasikan kasus data dan menghasilkan keputusan IPS. Nilai atribut tinggi mengklasifikasikan kasus data dan menghasilkan 
Vol. 8, No. 1, Maret 2019, ISSN : 2089-9033, eISSN : 2715-7849

keputusan Bahasa. Perhitungan node 1.2.1 ditunjukan pada Tabel 6.

Tabel 6. Perhitungan node 1.2.1

\begin{tabular}{|c|c|c|c|c|c|c|c|}
\hline ATRIBUT & VRUE & $\begin{array}{l}\text { JUNLAH } \\
\text { KaSSUS }\end{array}$ & $M P A$ & lPS & Banasa & ENTROPY & $\begin{array}{c}\text { INFORMAT ON } \\
\text { GHIN } \\
\end{array}$ \\
\hline TOTAL & & 13 & 0 & 4 & $\theta$ & $0,890 \angle 9164$ & \\
\hline \multirow[t]{4}{*}{ MINAT } & INIPA & 4 & 0 & 0 & 4 & 0 & \\
\hline & $1 \mathrm{PS}$ & 5 & 0 & 3 & 2 & 0,970950594 & \\
\hline & Bahasa & $i$ & 0 & 1 & 3 & 0,811278121 & \\
\hline & & & & & & & 0,267425060 \\
\hline \multirow[t]{4}{*}{ RAIIA-KA|ANIIISI } & 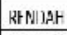 & a & 1] & 11 & 0 & 0 & \\
\hline & SEDANG & 11 & 0 & 1 & 7 & 0,530702107 & \\
\hline & TINGG| & 2 & 0 & 0 & 2 & 0 & \\
\hline & & & & & & & (1),4214:36/.3\% \\
\hline \multirow[t]{4}{*}{ NILNI Bahasa } & RENDSH & 0 & 0 & 0 & 0 & 0 & \\
\hline & SEDANG & 4 & 0 & 4 & 0 & 0 & \\
\hline & TINGG| & 9 & 0 & 0 & 9 & 0 & \\
\hline & & & & & & & 0,890491640 \\
\hline
\end{tabular}

Dari hasil perhitungan node 1.3 untuk kondisi Nilai IPA tinggi pada Gambar 5 didapatkan nilai gain tertinggi tertinggi 0, 156237374 pada Nilai IPS. Ada tiga nilai atribut nilai IPS yaitu rendah, sedang dan tinggi. Nilai atribut rendah mengklasifikasikan kasus data dan menghasilkan keputusan IPA. Sedangkan atribut sedang dan atribut tinggi belum dapat mengklasifikasikan kasus data dan belum menghasilkan keputusan. Untuk itu dilanjutkan perhitungan entropy dan gain pada kondisi Nilai IPA tinggi dan Nilai IPS sedang, dan kondisi Nilai IPA tinggi dan Nilai IPS tinggi. Perhitungan node 1.3 ditunjukkan pada Tabel 7.

Tabel 7. Perhitungan node 1.3

\begin{tabular}{|c|c|c|c|c|c|c|c|}
\hline ATIFU $\pi$ & VA:IIF & $\begin{array}{l}\text { JUMLAH } \\
\text { KinSUS }\end{array}$ & MIPA & IFS & Raดลุล & FNTRกPY & $\begin{array}{l}\text { INFCRMLATION } \\
\text { GAIN }\end{array}$ \\
\hline IUIAL & & sb & su & 4 & 1 & 0,360223311 & \\
\hline \multirow{4}{*}{ MINAT } & MMI'A & $5 b$ & 35 & $\mathrm{c}$ & 0 & u & \\
\hline & IPS & 18 & 21 & 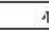 & & $c, 761201507$ & \\
\hline & Bahasa & 12 & 11 & 0 & 1 & 0,11381685 & \\
\hline & & & & & & & 0,144970572 \\
\hline \multirow{4}{*}{$\begin{array}{l}\text { RATA-RATA } \\
\text { NILA }\end{array}$} & REND,NH & 1 & 0 & 1 & 0 & 0 & \\
\hline & SEDiNG & 33 & 30 & 3 & 0 & 0,139196987 & \\
\hline & TINGGI & 51 & 50 & c & 1 & $c, 139232999$ & \\
\hline & & & & & & & 0,111055276 \\
\hline \multirow{4}{*}{ NIILI IPS } & RENDAH & 13 & 13 & 0 & 0 & 0 & \\
\hline & SEDANG & 51 & 60 & 0 & 1 & $c, 120581014$ & \\
\hline & $\pi N G G \mid$ & 11 & 7 & $\pi$ & 0 & 0,915550305 & \\
\hline & & & & & & & $0,15 c 237374$ \\
\hline \multirow{4}{*}{$\begin{array}{l}\text { NIII A } \\
\text { Bahas: }\end{array}$} & RENDAH & 6 & 5 & 1 & 0 & $0, \bar{c} 50322422$ & \\
\hline & SFTANG & 78 & 75 & 3 & 0 & $(0,23,51$ ๑3३३? & \\
\hline & กกลสดI & 1 & 0 & $\mathrm{c}$ & 1 & $n$ & \\
\hline & & & & & & & $0,10331<867$ \\
\hline
\end{tabular}

Dari hasil perhitungan node 1.3.1 untuk kondisi Nilai IPA tinggi dan Nilai IPS sedang pada Gambar 9 didapatkan nilai gain tertinggi 0,120681014 pada Nilai Bahasa. Ada tiga nilai atribut nilai Bahasa yaitu rendah, sedang dan tinggi. Nilai atribut rendah mengklasifikasikan kasus data dan menghasilkan keputusan IPA. Nilai atribut sedang mengklasifikasikan kasus data dan menghasilkan keputusan IPA. Nilai atribut tinggi mengklasifikasikan kasus data dan menghasilkan keputusan Bahasa. Perhitungan node 1.3.1 ditunjukkan pada Tabel 8.

Tabel 8. Perhitungan node 1.3.1

\begin{tabular}{|c|c|c|c|c|c|c|c|}
\hline ATRIBUT & VALLE & $\begin{array}{l}\text { IUMLAH } \\
\text { KASUS }\end{array}$ & MIPA & IPS & Dahasa & ENTROPY & $\begin{array}{l}\text { INFORMIATION } \\
\text { GIIN }\end{array}$ \\
\hline TOTAL & & 61 & 50 & 0 & 1 & 0,120581011 & \\
\hline \multirow[t]{4}{*}{ MINAT } & MIPA. & 37 & 37 & 0 & 0 & 0 & \\
\hline & IPS & 12 & 12 & 0 & 0 & 0 & \\
\hline & Behasa & 12 & 11 & 0 & 1 & 0,41381685 & \\
\hline & & & & & & & $0,0342 / 4421$ \\
\hline \multirow{4}{*}{$\begin{array}{l}\text { RATA-RATA } \\
\text { N LiI }\end{array}$} & RENDAH & 0 & 0 & 0 & 0 & 0 & \\
\hline & SEDANG & 29 & 29 & 0 & 0 & 0 & \\
\hline & TINGGI & 32 & 31 & 0 & 1 & 0,200522324 & \\
\hline & & & & & & & 0,015436516 \\
\hline \multirow{4}{*}{$\begin{array}{l}\text { N LAI } \\
\text { Bahasa }\end{array}$} & RENDAH & 5 & 5 & 0 & 0 & 0 & \\
\hline & SEDANG & 55 & 55 & 0 & 0 & 0 & \\
\hline & TINGGI & 1 & 0 & 0 & 1 & 0 & \\
\hline & & & & & & & 0,120581014 \\
\hline
\end{tabular}

Dari hasil perhitungan node 1.3.2 untuk kondisi Nilai IPA tinggi dan Nilai IPS tinggi pada Gambar 10 didapatkan nilai gain tertinggi 0, pada Minat. Ada tiga nilai atribut nilai Minat yaitu IPA, IPS, dan Bahasa. Minat dengan atribut IPA mengklasifikasikan kasus data dan menghasilkan keputusan IPA. Minat dengan atribut IPS mengklasifikasikan kasus data dan menghasilkan keputusan IPS. Sedangkan minat dengan atribut Bahasa tidak mengklasifikasikan kasus data dan tidak menghasilkan keputusan karena mempunyai nilai 0 semua. Perhitungan node 1.3.2 ditunjukkan pada Tabel 9.

Tabel 9. Perhitungan node 1.3.2

\begin{tabular}{|c|c|c|c|c|c|c|c|}
\hline संRAIIT & VELIIIF & $\begin{array}{l}\text { JUMLiH } \\
\text { KASUS }\end{array}$ & MAF & IPS & Rahax: & FNTRRPY & $\begin{array}{l}\text { INFOAMAATIOY } \\
\text { GAIN }\end{array}$ \\
\hline TO-AL. & & 11 & $?$ & 4 & 0 & 0 & 0 \\
\hline \multirow[t]{4}{*}{ MINit } & MIPA & 7 & 7 & 0 & 0 & 0 & 0 \\
\hline & irs & 4 & 0 & 7 & 0 & 0 & 0 \\
\hline & Eshasa & c. & 0 & 0 & 0 & 0 & 0 \\
\hline & & & & & & & C.9ะ556030450054 \\
\hline \multicolumn{8}{|l|}{ FATA-RATA. } \\
\hline \multirow[t]{4}{*}{ NIILAI } & FENDAH & 1 & 0 & 1 & & 0 & 0 \\
\hline & SEDANG & 4 & 1 & 3 & & $0.811278124<5913$ & \\
\hline & TIYGG| & 5 & 6 & 0 & 0 & 0 & 0 \\
\hline & & & & & & & $0 \quad 0.55055007752459$ \\
\hline \multicolumn{8}{|l|}{ NIILAI } \\
\hline \multirow[t]{4}{*}{ Eghesa } & FENDAH & 1 & 0 & 1 & 0 & D & \\
\hline & SEDANG & 10 & 7 & 3 & & 0.88129889923069 & \\
\hline & $T|Y G G|$ & $c$ & 0 & 0 & 0 & $c$ & \\
\hline & & & & & & & C. 12448675984547 \\
\hline
\end{tabular}

Dari semua perhitungan entropy dan gain tiap atribut dapat dibuat rule pohon keputusan sebagai berikut:

1. Jika Nilai IPA rendah dan Nilai IPS sedang maka jurusan Bahasa.

2. Jika Nilai IPA rendah dan Nilai IPS tinggi maka jurusan IPS.

3. Jika Nilai IPA=sedang dan Nilai IPS=rendah maka jurusan Bahasa.

4. Jika Nilai IPA=sedang dan Nilai IPS=sedang dan Nilai Bahasa=sedang maka jurusan IPS. 
5. Jika Nilai IPA=sedang dan Nilai $\mathrm{IPS}=$ sedang dan Nilai Bahasa=sedang maka jurusan Bahasa.

6. Jika Nilai IPA=sedang dan Nilai IPS=tinggi maka jurusan IPS.

7. Jika Nilai IPA=tinggi dan Nilai IPS=rendah maka jurusan IPA.

8. Jika Nilai IPA=tinggi dan Nilai IPS=sedang dan Nilai Bahasa rendah maka jurusan IPA.

9. Jika Nilai IPA=tinggi dan Nilai IPS=sedang dan Nilai Bahasa sedang maka jurusan IPA.

10. Jika Nilai IPA=tinggi dan Nilai IPS=sedang dan Nilai Bahasa tinggi maka jurusan Bahasa.

11. Jika Nilai IPA=tinggi dan Nilai IPS=tinggi dan minat=IPA maka jurusan IPA.

12. Jika Nilai IPA=tinggi dan Nilai IPS=tinggi dan minat=IPS maka jurusan IPS.

\subsubsection{Implentasi Sistem}

Implementasi sistem merupakan bentuk pelaksanaan atau penerapan dari model Algoritma C4.5 dalam bentuk sistem berbasis website. Hasil yang didapatkan dalam penelitian ini berupa sebuah sistem penentuan jurusan siswa menggunakan Algoritma C4.5. Sistem yang dikembangkan mempunyai beberapa menu seperti menu Home, menu Data Training, menu Data Testing, menu Perhitungan C4.5 dan menu Prediksi. Sebelum admin dapat mengakses meu, sebelumnya admin melakukan login dengan memasukkan username dan password.

\section{a. Halaman Login}

Halaman Login digunakan sebagai langkah awal admin agar dapat masuk ke menu yang disediakan dalam sistem. Halaman Login dapat dilihat pada Gambar 1.

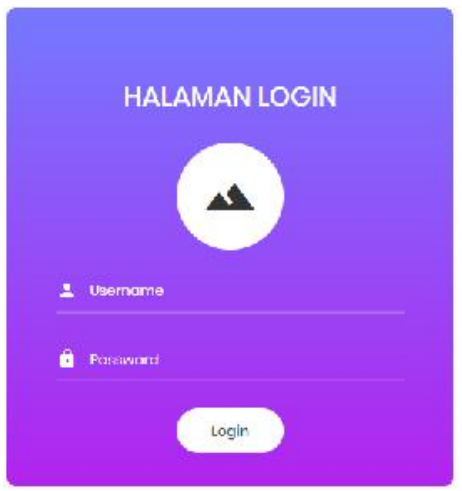

Gambar 1. Halaman Login

b. Halaman Home

Halaman Home merupakan halaman awal setelah admin berhasil melakukan login. Pada halaman ini ada menu seperti menu Data Training, menu Data Testing, menu Perhitungan C4.5, menu Prediksi dan tombol logout. Halaman Home dapat dilihat pada Gambar 2.

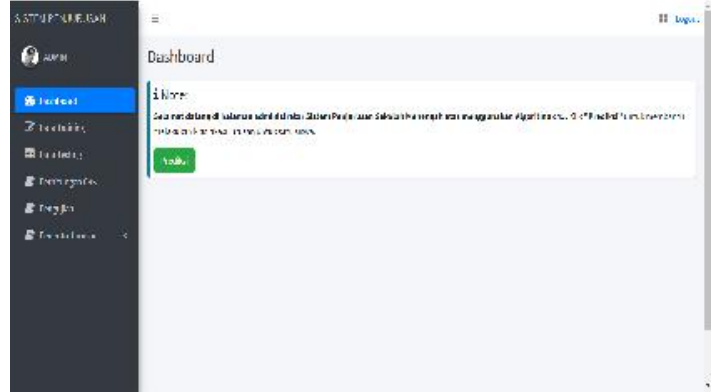

Gambar 2. Halaman Home

c. Halaman Data Training

Halaman data training berfungsi menampilkan daftar data training yang telah ditambahkan. Pada halaman ini dapat menambahkan data dengan mengisi form yang disediakan ketika mengakses pada tombol tambah data atau dapat menambahkan data melalui tombol import excel. Selain itu data yang telah ditambahkan dapat diubah dan dihapus jika terdapat kesalahan dalam penulisannya. Halaman Data Training dapat dilihat pada Gambar 3.

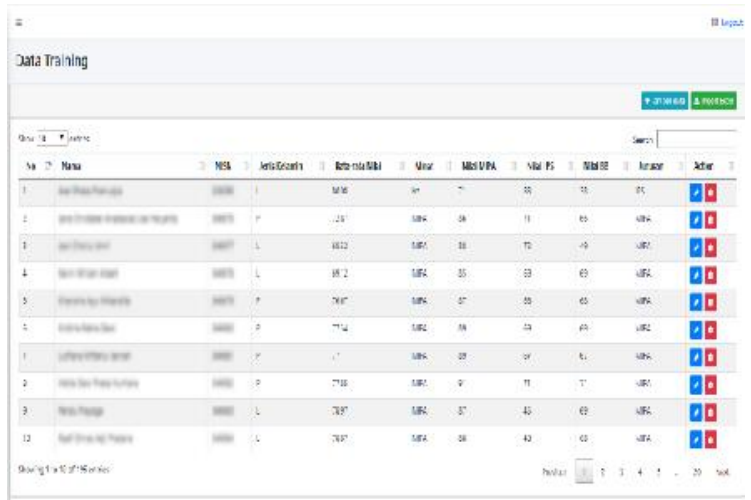

Gambar 3. Halaman Data Training

d. Halaman Data Testing

Halaman data testing berfungsi menampilkan daftar data training yang telah ditambahkan. Pada halaman ini dapat menambahkan data dengan mengisi form yang disediakan ketika mengakses pada tombol tambah data atau dapat menambahkan data melalui tombol import excel. Selain itu data yang telah ditambahkan dapat diubah dan dihapus jika terdapat kesalahan dalam penulisannya. Halaman Data Testing dapat dilihat pada Gambar 4. 


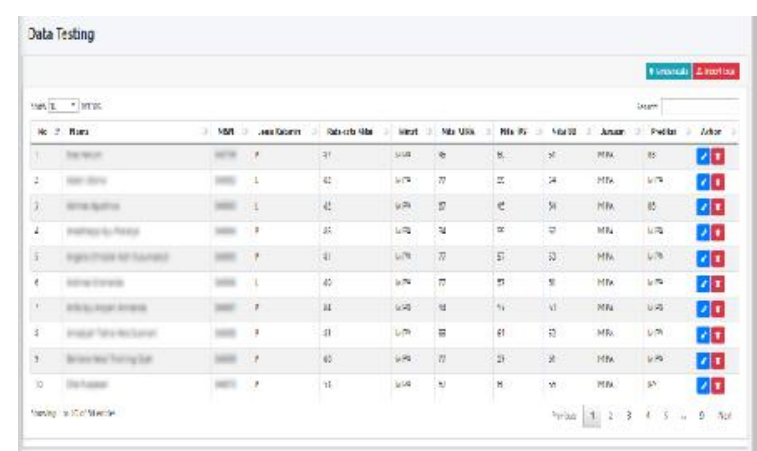

Gambar 4. Halaman Data Testing

e. Halaman Perhitungan C4.5.

Halaman Perhitungan C4.5 menampilkan hasil perhitungan data training menggunakan perhitungan Algoritma C4.5. Perhitungan algoritma ini meliputi perhitungan gain dan entropy dari setiap atribut untuk membentuk pohon keputusan. Kemudian setelah semua atribut memiliki pohon keputusan makan dibentuk rule pohon keputusan guna diterapkan dalam data testing untuk melakukan proses penentuan jurusan. Halaman Perhitungan C4.5. dapat dilihat pada Gambar 5. Sedangkan halaman rule pohon keputusan dapat dilihat pada Gambar 6.

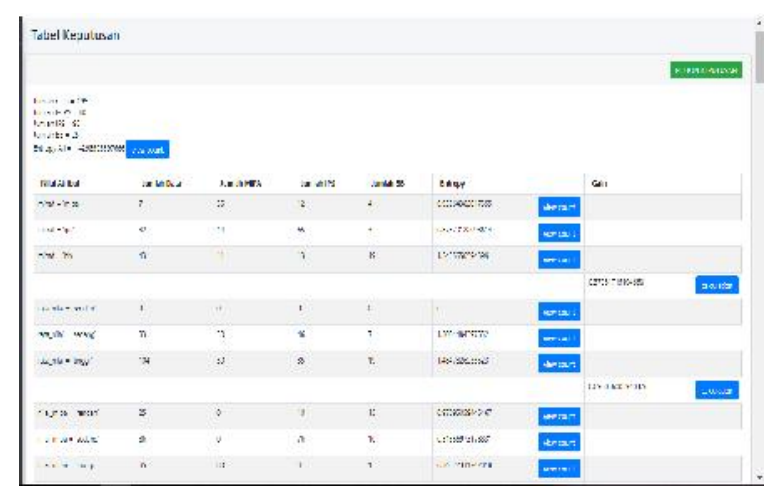

Gambar 5. Halaman Perhitungan C4.5

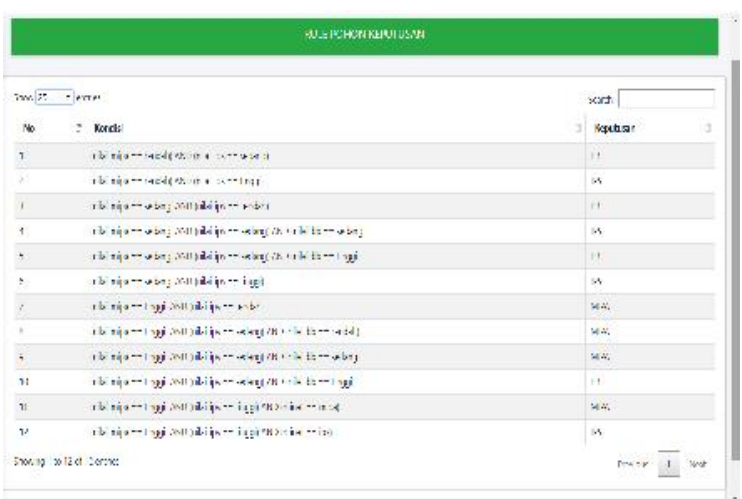

Gambar 6. Halaman Rule Pohon Keputusan f. Halaman Prediksi

Halaman prediksi berfungsi untuk melakukan prediksi jurusan terhadap satu siswa dimana perlu adanya input data seperti nama, nisn, minat, nilai rata-rata raport, nilai IPA, nilai IPS, dan nilai Bahasa. Setelah adanya input data maka diklasifikasikan jurusan berdasarkan model pengetahuan rule yang didapat. Halaman input prediksi dapat dilihat pada Gambar 7 dan halaman prediksi jurusan ditunjukkan pada Gambar 8. Sedangkan untuk melihat daftar data hasil prediksi ditunjukkan pada Gambar 18.

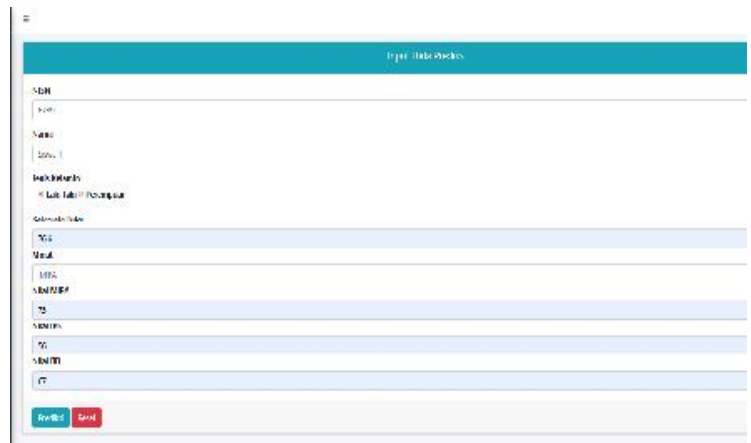

Gamabr 7. Halaman input prediksi

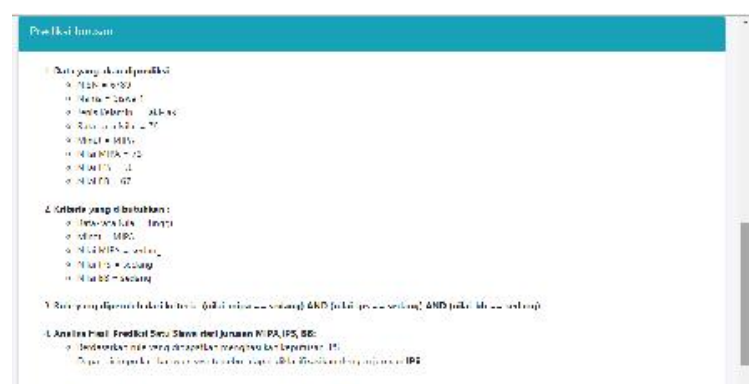

Gambar 8. Halaman Prediksi Jurusan

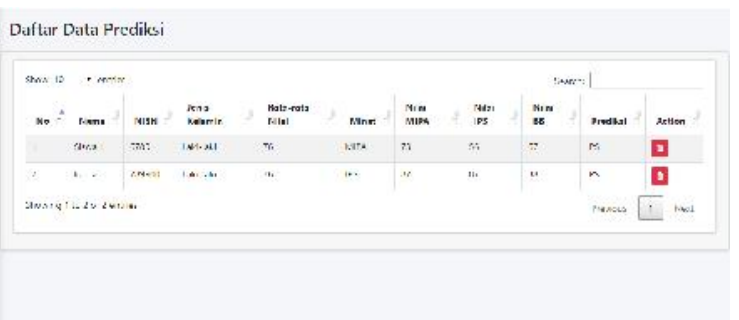

Gambar 9. Halaman Daftar Data Prediksi

\subsection{Pengujian}

Pengujian dilakukan dengan software rapid miner untuk mengetahui nilai accuracy, recall dan precision dengan Algoritma C4.5. Data yang digunakan dalam pengujian adalah data testing yang terdiri dari 196 record dan 5 
atribut. Disini penulis menggunakan cross validation sebagai proses validasi. Kemudian akan diperoleh hasil accuracy, recall dan precision.

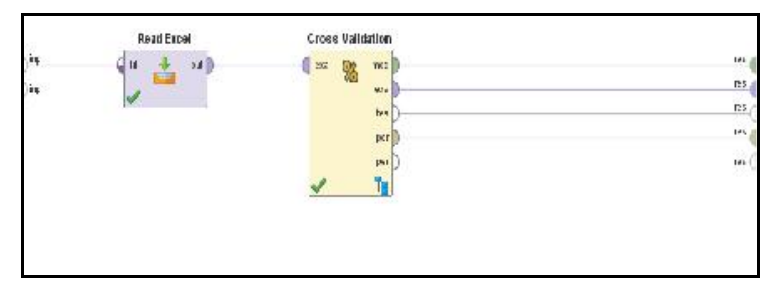

Gambar 10. Cross Validation dengan Algoritma C4.5

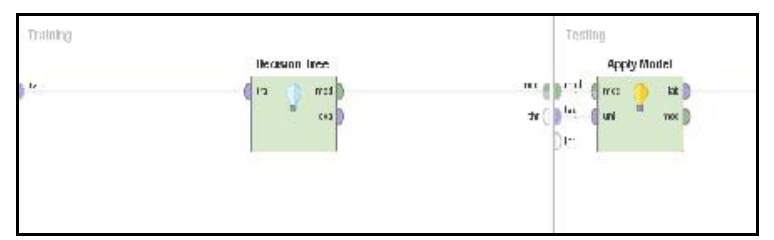

Gambar 11. Cross Validation dengan Algoritma $\mathrm{C} 4.5$

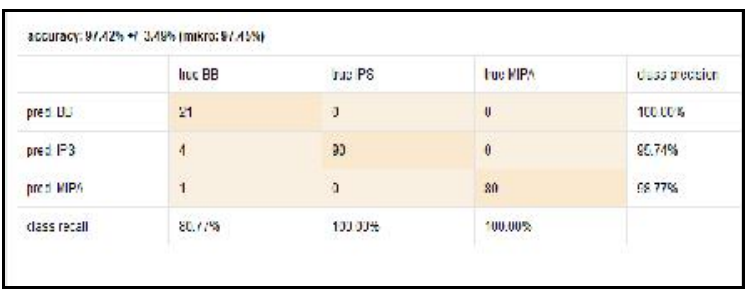

Gambar 12. Perhitungan Accuracy, Recall, dan Precision

Dari perhitungan menggunakan Rapid Miner menghasilkan nilai accuracy sebesar $97.42 \%$.

$$
\begin{aligned}
\text { Nilai recall } & =\frac{\text { recall Bahasa }+ \text { recallIPS }+ \text { recall } I P A}{8^{80.77+100+100}} \\
& =\frac{3}{3}^{3} \\
& =93.59 \%
\end{aligned}
$$$$
\begin{aligned}
\text { Nilai precision }(P) & =\frac{P . \text { Bahasa }+ \text { P.IPS }+ \text { P.IPA }}{3} \\
& =\frac{100+95.74+98.77}{3} \\
& =98.17 \%
\end{aligned}
$$

\section{PENUTUP}

Dari hasil penilitan yang dilakukan dapat ditarik kesimpulan sebagai berikut:

a. Algoritma C4.5 dapat memudahkan dalam pengambilan keputusan dalam penentuan jurusan siswa dan dapat mengklasifikasikan 3 kelas jurusan yaitu IPA, IPS, dan Bahasa. b. Perhitungan Algoritma C4.5 menggunakan Excel dan menggunakan aplikasi sistem menghasilkan rule pohon keputusan yang sama.

c. Rule yang didapatkan dari perhitungan Algoritma C4.5 berjumlah 12 buah dan digunakan untuk proses penentuan jurusan siswa.

d. Penerapan Algoritma C4.5 menghasilkan Nilai Accuracy dengan Rapid Miner sebesar 97,42 \%, menghasilkan precision sebesar $98,17 \%$ dan recall sebesar $93,59 \%$.

Adapun saran dalam pengembangan sistem untuk hasil prediksi yang lebih akurat dibutuhkan data dalam jumlah yang besar agar semakin akurat dan pengetahuan yang dihasilkan menjadi lebih baik.

\section{DAFTAR PUSTAKA}

[1] I. Sujai, Purwanto, and H. Himawan, "Prediksi Hasil Jurusan Siswa Sekolah Menengah Atas Dengan Menggunakan Algoritma Decision Tree C4.5," vol. 12, no. April, pp. 42-53, 2016.

[2] N. Azwanti, "Algoritma C4.5 Untuk Memprediksi Mahasiswa Yang Mengulang Mata Kuliah (Studi Kasus Di Amik Labuhan Batu)," Simetris J. Tek. Mesin, Elektro dan Ilmu Komput., vol. 9, no. 1, pp. 11-22, 2018.

[3] Y. S. Nugroho, "Penerapan Algoritma C4.5 Untuk Klasifikasi Predikat Kelulusan Mahasiswa Fakultas Komunikasi Dan Informatika Universitas Muhammadiyah Surakarta," no. November, pp. 1-6, 2014.

[4] L. Swastina, "Penerapan Algoritma C4 . 5 Untuk Penentuan Jurusan Mahasiswa," vol. 2, no. 1, 2013.

[5] S. L. B. Ginting, W. Zarman, and I. Hamidah, "Analisis dan Penerapan Algoritma C4.5 dalam Data Mining untuk Memprediksi Masa Studi Mahasiswa Berdasarkan Data Nilai Akademik," Pros. Semin. Nas. Apl. Sains Teknol., vol. 3, no. November, pp. 211-216, 2014.

[6] A. G. Mabrur and L. Riani, "Penerapan Data Mining Untuk Memprediksi Kriteria Nasabah Kredit," Jurnal Ilmiah Komputer dan Informatika (KOMPUTA), vol. 1, no. 1, pp. 53-57, 2012.

[7] M. Agushinta, D., Irfan, "Perancangan Aplikasi Data Mining Untuk Memprediksi Permintaan Customer Pada Perusahaan Persewaan Mobil, Prosiding Seminar Ilmiah Nasional Komputer dan Sistem Intelijen (KOMMIT)," Univ. Gunadarma, no. Kommit, pp. 20-21, 2008.

[8] R. P. S. Putri and I. Waspada, "Penerapan Algoritma C4.5 pada Aplikasi Prediksi Kelulusan Mahasiswa Prodi Informatika," Khazanah Inform. J. Ilmu Komput. dan 
Inform., vol. 4, no. 1, p. 1, 2018.

[9] D. Dharmayanti, A. M. Bachtiar, A. C. Prasetyo, T. Informatika, U. Komputer, and J. D. Bandung, "Penerapan Metode Clustering untuk Membentuk Kelompok Belajar Menggunakan di SMPN 19 Bandung," Jurnal Ilmiah Komputer dan Informatika (KOMPUTA), vol. 6, no. 2, 2017.

[10] S. M. Khoiroh, "Implementasi Data Mining dengan Algoritma C4.5 untuk memprediksi Prestasi Siswa," no. 6, pp. 67-72, 2017.

[11] T. Vafeiadis, K. I. Diamantaras, G. Sarigiannidis, and K. C. Chatzisavvas, "A comparison of machine learning techniques for customer churn prediction," vol. 1-9, p. $55,2015$. 